\title{
SCIENTIFIC BASIS FOR BANANA CULTIVAR PROPORTIONS ON-FARM IN EAST AFRICA
}

\author{
G. NANTALE, E.K. KAKUDIDI, D.A. KARAMURA ${ }^{1}$, E. KARAMURA ${ }^{1}$ and G. SOKA ${ }^{1}$ \\ Botany Department, Makerere University, P.O. Box 7062, Kampala, Uganda \\ ${ }^{1}$ Bioversity International, P.O. Box 24384, Kampala, Uganda
}

\begin{abstract}
Banana (Musa spp.) production and diversity in the East African region, has been on the decline for the last 20 years due to both a biotic and biotic problems. There has been an ecological and socio-economic imbalance in the East African Highland banana (Musa AAA-EA) growing systems due to this decline. However, farmers have been growing these bananas in cultivar mixtures, a practice which ensures the continuous sustainability of the system. Cultivar mixtures, however, seem to be in specific proportions based on the strength and weakness of each cultivar and so affecting the clone sets to which cultivars belong, as well as providing predictions on the conservation status of each clone set. The primary objective of the study was to account for the farmers' perceptions behind cultivar proportions and to understand the scientific basis of these proportions in selected sites in East Africa. The study was carried out in Karagwe, Bushenyi and Masaka districts in East Africa, a region considered to be a secondary centre of diversity for bananas. Thirty farms were sampled in one selected parish/ ward in the three sites for ecological data. The quadrat method was used to record abundances of identified cultivars in order to determine the cultivar proportions. Ethno-botanical data collected on traditional knowledge was analysed for twenty-three identified traditional cultivar-selection criteria used in the participatory rural appraisal (PRA), as well as interviews from 15 key informants of each study area. A total of 105 cultivars were identified, $76 \%$ of which were the East African Highland bananas. Although fourteen cultivars were common to the three sites, Masaka had the highest proportion with Nfuuka cultivar leading the five clone sets. Cultivar diversity indices explained the proportions in terms of richness and evenness and Nfuuka was the richest clone set. Although all clone sets were represented at each site, they were not evenly distributed; a factor which is disadvantageous in the conservation status of the crop. While results indicated that the agro-ecological and traditional utilisation criteria formed the basis for cultivar proportions on farm for both Karagwe and Masaka, farmers were found to do so because of the high traditional values attached to the crop. However, knowing cultivar proportions in terms of richness and evenness can assist in predicting the stability or change in diversity of banana growing sites.
\end{abstract}

Key Words: Highland, Musa spp., Tanzania, Uganda

\section{RÉSUMÉ}

La production et la diversité de la banane (Musa spp) dans cette région, a été sur le déclin pour le dernier 20 ans en raison des problèmes biotiques. Il y a eu un déséquilibre écologique et socio-économique dans la région montagneuse Africaine del 'Est (banane de montagne, Musa AAA-pièce) des systèmes de croissance en raison de ce déclin. Cependant, les agriculteurs ont grandi ces bananes dans les cultivars associés, une pratique qui garantit la durabilité continue du système d'association de cultivar, cependant, semble être dans les proportions spécifiques fondées sur la resistance et la faiblesse de chaque cultivar et affectant si les séries clones semblables aux lesquelles les cultivars appartiennent, de même que fournir les prédictions sur le statut de conservation de chaque série absolument semblable. L’objectif primaire de l'étude était de représenter les agriculteurs les perceptions derrière les proportions de cultivar et comprendre la base scientifique de ces proportions dans les sites choisis en Afrique de l'Est. L'étude a été exécuté dans Karagwe, les quartiers de Bushenyi et Masaka dans l'Afrique de l'est, une région considérée être un centre secondaire de diversité pour les bananes. Trente fermes 
ont été echantillonné dans une localité/section choisie dans les trois sites pour les données écologiques. La méthode de quadrat a été utilisée pour enregistrer des abondances de cultivars identifiés pour déterminer les proportions de cultivar. Les données Ethno-botaniques recueillies sur la connaissance traditionnelle ont été analysées pour vingt-trois critères de sélection traditionnelle de cultivar identifiés utilisés dans l'estimation rurale participative (PRA), de même que les entretiens de 15 informateurs clés de chaque secteur d'étude. Un total de 105 cultivars a été identifié, 76\% dont étaient les bananes de montagne de l'Afrique de l'Est. Bien que quatorze cultivars étaient communs aux trois sites, Masaka a eu la plus haute proportion de cultivar de Nfuuka menant les cinq séries des clones. Les index de diversité de cultivar ont expliqué les proportions sur le plan de la richesse et de l'égalité et Nfuuka était la série de clone la plus riche. Bien que toutes séries de clones aient été représentées à chaque site, ils n’ont pas été également distribués ; un facteur qui est défavorable dans le statut de conservation de la récolte. Pendant que les résultats ont indiqué que les critères d'utilisation agro-écologiques et traditionnels ont formé la base pour les proportions de cultivar sur la ferme pour Karagwe et Masaka, les agriculteurs ont été trouvés entrain de beaucoups travailler à cause des hautes valeurs traditionnelles attachées à la récolte. Cependant, sachant les proportions de cultivar sur le plan de la richesse et de l'égalité peuvent aider à prédire la stabilité ou le changement dans la diversité de croissance de banane dans les sites.

Mots Clés: La région montagneuse, Musa spp., La Tanzanie, Ouganda

\section{INTRODUCTION}

The Great Lakes region of East Africa is one of the secondary centres of diversity for bananas, yet the region has suffered a great decline in production and diversity for the last ten to twenty years (Karamura et al., 2004). In response to this decline, various efforts by national programmes have been made to collect and conserve ex-situ the genetic diversity for Musa sp. However, field ex-situ collections have been very expensive to maintain, and most collections have in the last two decades, been lost either due to civil strife or other factors. In addition, existing ex-situ collections have been characterised by insufficient farmer-crop interaction, which allows selection of a condition which favours increase in diversity particularly in vegetatively propagated crops.

On-farm in-situ conservation, on the other hand favours continuous farmers' interactions and thus has the potential to conserve and increase diversity and utilise farmers' traditional knowledge on the management and conservation of crop diversity (Brush, 1999; Loutte, 1999).

Traditional knowledge forms a basis for decision making in food security, human and animal health, education and natural resource management for farmers. A number of studies have been carried out to assess the possible links between farmers' knowledge, decision making and genetic variation in major crops (Teshome et al., 1999 a,b; Bellon, 1991; Loutte, 1999). The diversity of crops existing in specific location has always been found to be partly based on farmers' traditional knowledge of cultivars as well as their selection criteria employed. Farmers in the Great Lakes Region of East Africa have been selecting banana cultivars for hundreds of years and creating the large Musa diversity found in the region today (Karamura et al., 1999). Such diversity has allowed farmers to maximise and meet their household needs as well as sustaining the agro-ecosystems of the crop. In this regard, local knowledge associated with banana management and conservation plays a crucial role in integrated management of the whole system (Hammer and Mbewe, 1992). The link between traditional knowledge of cultivars of crops and diversity existing in an area is an aspect which needs validation and documentation because it serves multiple goals in the management of the crop agro-ecological system as well as household needs (food and incomes). There is need, therefore, to establish farmers' perceptions behind local knowledge connected with diversity of cultivars so that it can be validated to strengthen on farm conservation.

Growing banana cultivars in a mixture or proportions is a traditional practice farmers have been carrying out in support of management and conservation of diversity. Farmers carry out 
exclusively this practice through selection, production and utilisation using different types of knowledge on the crop. These observations, however, have not been examined scientifically in order to re-enforce farmers' conservation efforts. In this regard, the objectives of this study were to, determine local banana cultivar proportions, and establish farmers' perceptions behind this practice as well as understanding the scientific basis for these proportions.

\section{MATERIALS AND METHODS}

The study was conducted during 2004 and 2005 in Masaka and Bushenyi in Uganda, and Karagwe in Tanzania. In each of these districts, three to five parishes/villages that had been originally selected as Musa in-situ sites on the basis of having had a banana-based cropping system for a long time, diversity was still high though the agro-ecologies were different. Masaka is at a lower altitude (1080 to 1330 meters above sea level), while Bushenyi and Karagwe are located at $1,600-1,800$ meters above sea level. With the help of agricultural extensionists from the respective districts, five parishes were selected from one sub-county of Masaka and Bushenyi districts in Uganda and one division/village in Karagwe district, Tanzania. The selection of parishes was based on the availability of plantations with more than 200 mats. Thirty farmers were selected from the five parishes, that is, 6 farmers per parish and these were selected on the basis of their availability, willingness to participate and how knowledgeable they were on cultivars grown in their plantation.

On each farm, three transects were laid, one 5 $\mathrm{m}$ inside the plantation from the boundary, the rest at a regular interval of $10 \mathrm{~m}$ apart. A series of $5 \mathrm{~m}$ by $5 \mathrm{~m}$ quadrats were placed along each transect using strings alternating at a regular interval of $5 \mathrm{~m}$. Banana mats in each quadrat were labeled using flagging tapes (coloured polythene), identified by the farmer (owner) assisted by field assistants in that area and grouped into clone sets based on Karamura's (1999) East African Highland banana classification. Number of individuals per clone within a quadrat was recorded in pre-prepared record sheets. The location of each quadrat was also noted in relation to homestead, edge of plantation and within a plantation.

Cultivar proportions were determined by measures of cultivar abundance and were explained by determining cultivar richness and evenness. The cultivar richness and evenness were summarised through cultivar diversity indices based on; Shannon-Weaner diversity index:

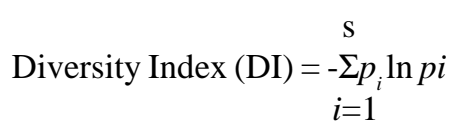

Where $\mathrm{s}=$ number of cultivars (or clones);

$\mathrm{P}_{i} \quad=$ the proportion of individuals or the abundance of the $i^{\text {th }}$ cultivar; expressed as a proportion of the total sample;

$\ln \quad=$ natural logarithm

Shannon's equitability/evenness, calculated as:

Equitability $\left(\mathrm{E}_{\mathrm{H}}\right)=\mathrm{DI} / \mathrm{DI}_{\max }=\mathrm{DI} / \ln \mathrm{S}$

Where: $S=$ total number of cultivar

To obtain the relationships between cultivar proportions and selection criteria, Principal Component Analysis (PCA) was employed using Numerical Taxonomy and Multivariate Analysis System (Ntsys) Package. For farmers' perceptions behind cultivar proportions on farm, focus group discussions and checklists were used. Fifteen farmers were selected as key informants from the original selected farms for the discussions, each carried out separately. The selection criteria for the key informants were based on the diversity on each farm and willingness to hold long discussions. The farmer discussions focused on selection, maintenance and utilisation of landrace diversity. Selection criteria were computed against cultivars grown in each site to determine correlations between the two.

\section{RESULTS}

Cultivar proportion in the studied areas. There were 14 common cultivars in the three studied sites (Fig. 1). Cultivars localised only in Masaka 
were thrice those in Bushenyi, while those localised in Karagwe were twice those in Bushenyi and only one Nalwezinga, was common in Bushenyi and Karagwe studied area.

At each site, Nfuuka clone set had the highest proportion, followed by Nakabululu clone set. The clone set proportion differs in the 3 sites. Masaka district had more different cultivars within each clone set compared to Bushenyi and Karagwe districts (Table 1). The five clone sets also differed with respect to number of cultivars per study area. Hence, farmers plant cultivars in different proportions per area studied and this may depend on the value of each cultivar in the respective site.

Cultivar proportions can be explained in terms of cultivar diversity indices which encompass richness and evenness of cultivars in a specified area (Table 2). Nfuuka clone set has far the highest richness of cultivars for each site although not very well evenly distributed. Other Clone sets have almost similar level of richness except Mbidde and Nakabululu in Masaka, which are slightly higher than other clone sets in the two other sites. Although Nakabululu clone set is the best evenly distributed clone set, cultivar evenness was generally low and differed much between the three studied areas indicating lower chances of frequency of occurrence of each cultivar recorded in each site (Table 2). From the observations clone set equitability/evenness ranged from 0.10 to 0.38 in three sites.

Farmers' perceptions behind cultivar proportions on farm. Figures 2, 3 and 4 show correlations resulting from PCA between cultivars and selection criteria. Cultivar proportions depend on the value of each cultivar to farmers

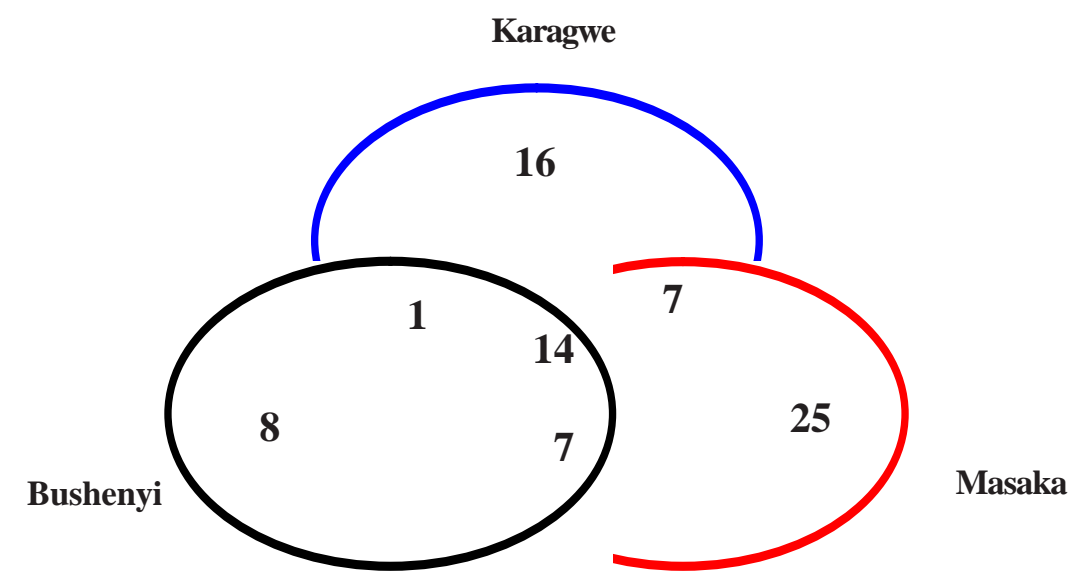

Figure 1. Distribution of cultivars in the study sites in East Africa.

TABLE 1. Clone set proportions in respective studied areas of East Africa

\begin{tabular}{lccc}
\hline Clone sets & Bushenyi & Karagwe & Masaka \\
\hline Mbidde & 3 & 11 & 4 \\
Nfuuka & 78 & 39 & 36 \\
Nakitembe & 12 & 3 & 16 \\
Musakala & 2 & 18 & 11 \\
Nakabululu & 5 & 29 & 33 \\
Total & 100 & 100 & 100 \\
\hline
\end{tabular}


TABLE 2. Diversity indices for different clone sets in the study sites in East Africa

\begin{tabular}{llllllll}
\hline Study area & $\begin{array}{l}\text { Diversity } \\
\text { indices }\end{array}$ & Clones & \multicolumn{5}{c}{ Clone sets } \\
\cline { 3 - 7 } & & & Mbidde(B) & Nfuuka(F) & Nakitembe(K) & Musakala(M) & Nakabululu(N) \\
\hline \multirow{2}{*}{ Karagwe } & Richness & 38 & 5 & 19 & 4 & 5 & 5 \\
& Evenness & 0.31 & 0.13 & 0.26 & 0.29 & 0.21 & 0.31 \\
& DI & 1.15 & 0.22 & 0.76 & 0.40 & 0.33 & 0.51 \\
& & & & & & & \\
Bushenyi & Richness & 30 & 5 & 12 & 4 & 4 & 5 \\
& Evenness & 0.20 & 0.10 & 0.14 & 0.34 & 0.38 & 0.23 \\
& DI & 1.15 & 0.22 & 0.76 & 0.40 & 0.33 & 0.51 \\
& & & & & & & \\
Masaka & Richness & 54 & 10 & 21 & 7 & 6 & 10 \\
& Evenness & 0.31 & 0.37 & 0.23 & 0.21 & 0.32 & 0.27 \\
& DI & 1.23 & 0.84 & 0.69 & 0.40 & 0.58 & 0.62 \\
\hline
\end{tabular}

Key: DI = Diversity index

and, hence, the cultivar selection criteria of farmers have a part to play in the cultivar proportions on farm. In Karagwe, cultivars of only four green-cooking clone sets (F-Nfuuka; K-Nakitembe; M-Musakala; N-Nakabululu) are highly correlated with food security, finger size, ease of peeling, food texture and resistance to pests and diseases. Cultivars of Mbidde clone set are not particularly correlated with any selection criterion, while at the same time other selection criteria are not directly correlated with cultivars.

In Bushenyi, cultivars are selected specifically for their end use as well as their finger size. Among the criteria which are highly correlated with cultivars are beverage making, roasting, flour making and finger size. However, a number of some criteria were not directly correlated with cultivars. These include resistance to pests, drought tolerance, soil adaptability, bunch compactness, height of pseudostem and new cultivars. In Masaka, cultivar selection correlated with all criteria except with the location, flour making and food security. The fact that many of the selection criteria were important in Masaka, may explain the high level of diversity in that part of Uganda.

\section{DISCUSSIONS}

While farmers are responsible for selecting cultivars on farm, the proportion of cultivars they have can be explained scientifically through cultivar diversity index which utilises cultivar richness, frequency and abundances to predict their conservation status. Nfuuka was noted as the most diverse clone set and this may be because it mutates more frequently than other clone sets (Karamura, 1999), hence the highest richness of the clone sets. On the other hand Nakabalulu clone set which had a low value for richness was found to be more evenly distributed than Nfuuka and, hence, would have more chances of survival than Nfuuka. Nfuuka is a commercial clone set due to having heavy compacted bunches although most members of the clone set are slow to mature and food texture not so good. However, Nakabululu clones are soft textured, tasty and very quick to mature but they are small fingered and bunched plants, hence not commercial (Karamura, 1999). Finger size as a selection criteria directly correlated with cultivars in Bushenyi and Karagwe. This is because the consumers prefer long and slender fingers than short and stumpy ones. 


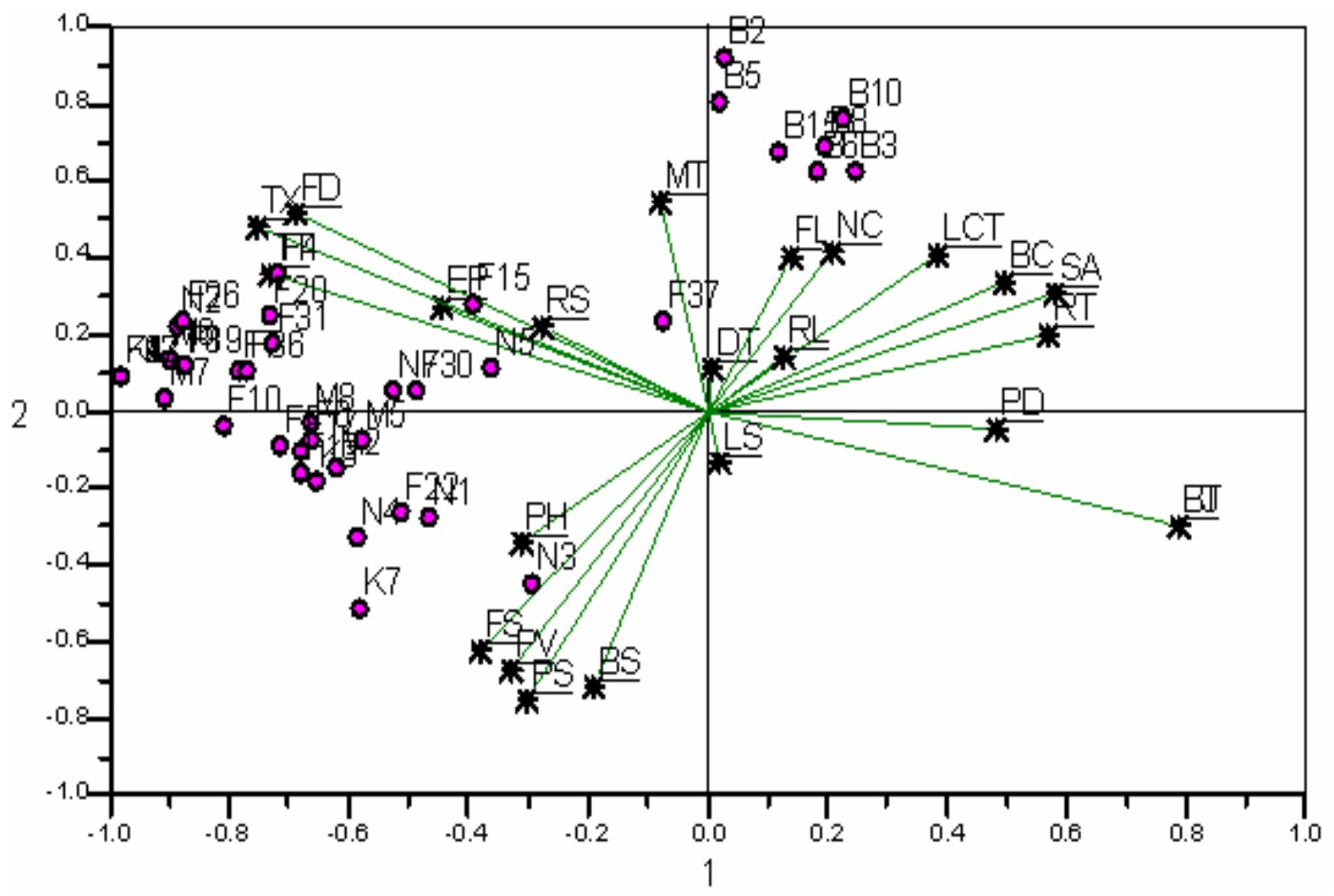

Key: 1. * farmers' selection criteria $\bullet$ Cultivar

2. Cultivar Location-LCT; Soil adaptability-SA; Pseudostem size-PS; Bunch compactness-BC; Bunch size-BS; Brewing and Juice making-BJ; Drought tolerance-DT; Ease of peeling-EP; Flour-FL; Food-FD; Food security-FT; Finger size-FS; Texture-TX; Taste-TT; Maturity-MT; New cultivar-NC; Plant vigour-PV; Pseudostem height-PH; Ratooning-RT; Resistance to pests and diseases-PD; Rituals-RL; Roasting-RS; Leaf size-LS

3. B-Mbidde; F-Nfuuka; K-Nakitembe; M-Musakala; N-Nakabululu

4. Bagandeseza-B1; Kyamalindi-B10; Mbwazirume embidde-B11 Nalukira-B12; Nalwesaanya-B13; Nsowe-B14; Nunda-B15; Shombo-buleku-B16; Endemera-B2; Enigwa-B3; Enkara-B4; Enkundi-B5; Entabura-B6; EntukuraB7; Entundu (B)-B8 Kabula-B9; Atwalira-F1; Enzirabahima-F10; Enzirabahima omweru-F11; Kakirya-F12; KatwaloF13; Kavube-F14; Kibidebide-F15; Kigerekyanvubu-F16; Kyabuyange-F17; Lusumba-F18; Lwaduungu-F19; Bukumu-F2; Mukazi-mugumba-F20; Musaj''atuuba-F21; Nabusa-F22; Nabusa-omuddugavu-F23; NakawangaaziF24; Nakawere-F25; Nakinyika-F26; Nalwezinga-F27; Nambi-F28; Nambi omumyufu-F29; Embogo-F3; Ndiibwabalangira-F30; Nfuuka-F31; Ntika-F32; Pemba-F33; Ruzongoma-F34; Rwambarara-F35; Siira-F36; EngumbaF4; Enkonkomore-F5; Entariho-F6; Entokatoke-F7; Entundu-F8; Enyiraguju-F9; Mbwazirume-K1; Mbwazirume omweru-K2; Nakitembe-K3; Namaliga-K4; Namaliga omunene-K5; Namwezi-K6; Nandigobe-K7; Africa-M1; Lwewunzika-M2; Lwewunzika-M3; Mpologoma-M4; Musakala-M5; Musakala omuddugavu-M6; MuseneneM7; Muvubo-M8; Butobe-N1; Nakabululu omutono-N10; Nakyetengu-N11; Salalugazi-N12; Enteka katebe-N2; Entente-N3; Kattabunyonyi-N4; Kibuzi-N5; Mukubakkonde-N6; Nakabululu-N7; Nakabululu omudugavu-N8; Nakabululu omunene-N9.

Figure 2. Correlation between farmer cultivar selection criteria against cultivars in Karagwe in Tanzania.

From the study, Masaka is diverse in local cultivars compared to Karagwe and Bushenyi. The different selection criteria were almost all directly correlated with the different cultivars grown on site in Masaka, which has been maintaining a banana based system for a long 




2. Cultivar Location-LCT; Soil adaptability-SA; Pseudostem size-PS; Bunch compactness-BC; Bunch size-BS; Brewing and Juice making-BJ; Drought tolerance-DT; Ease of peeling-EP; Flour-FL; Food-FD; Food security-FT; Finger size-FS; Texture-TX; Taste-TT; Maturity-MT; New cultivar-NC; Plant vigour-PV; Pseudostem height-PH; Ratooning-RT; Resistance to pests and diseases-PD; Rituals-RL; Roasting-RS; Leaf size-LS

3. B-Mbidde; F-Nfuuka; K-Nakitembe; M-Musakala; N-Nakabululu

4. Bagandeseza-B1; Kyamalindi-B10; Mbwazirume embidde-B11 Nalukira-B12; Nalwesaanya-B13; Nsowe-B14; Nunda-B15; Shombo-buleku-B16; Endemera-B2; Enigwa-B3; Enkara-B4; Enkundi-B5; Entabura-B6; EntukuraB7; Entundu (B)-B8 Kabula-B9; Atwalira-F1; Enzirabahima-F10; Enzirabahima omweru-F11; Kakirya-F12; Katwalo-F13; Kavube-F14; Kibidebide-F15; Kigerekyanvubu-F16; Kyabuyange-F17; Lusumba-F18; LwaduunguF19; Bukumu-F2; Mukazi-mugumba-F20; Musaj''atuuba-F21; Nabusa-F22; Nabusa-omuddugavu-F23; Nakawangaazi-F24; Nakawere-F25; Nakinyika-F26; Nalwezinga-F27; Nambi-F28; Nambi omumyufu-F29; Embogo-F3; Ndiibwa-balangira-F30; Nfuuka-F31; Ntika-F32; Pemba-F33; Ruzongoma-F34; Rwambarara-F35; Siira-F36; Engumba-F4; Enkonkomore-F5; Entariho-F6; Entokatoke-F7; Entundu-F8; Enyiraguju-F9; MbwazirumeK1; Mbwazirume omweru-K2; Nakitembe-K3; Namaliga-K4; Namaliga omunene-K5; Namwezi-K6; NandigobeK7; Africa-M1; Lwewunzika-M2; Lwewunzika-M3; Mpologoma-M4; Musakala-M5; Musakala omuddugavuM6; Musenene-M7; Muvubo-M8; Butobe-N1; Nakabululu omutono-N10; Nakyetengu-N11; Salalugazi-N12; Enteka katebe-N2; Entente-N3; Kattabunyonyi-N4; Kibuzi-N5; Mukubakkonde-N6; Nakabululu-N7; Nakabululu omudugavu-N8; Nakabululu omunene-N9.

Figure 3. Correlation between farmer cultivar selection criteria against cultivars in Bushenyi in Uganda.

time and the crop is part and parcel of the farming communities. In this district the crop is also grown for commercial ends since the district is close to major urban markets. Conversely, Karagwe which too has had a long time banana-cultivation culture, has not been able to commercialise the crop because of remoteness from the markets. Bushenyi has low diversity probably because it 


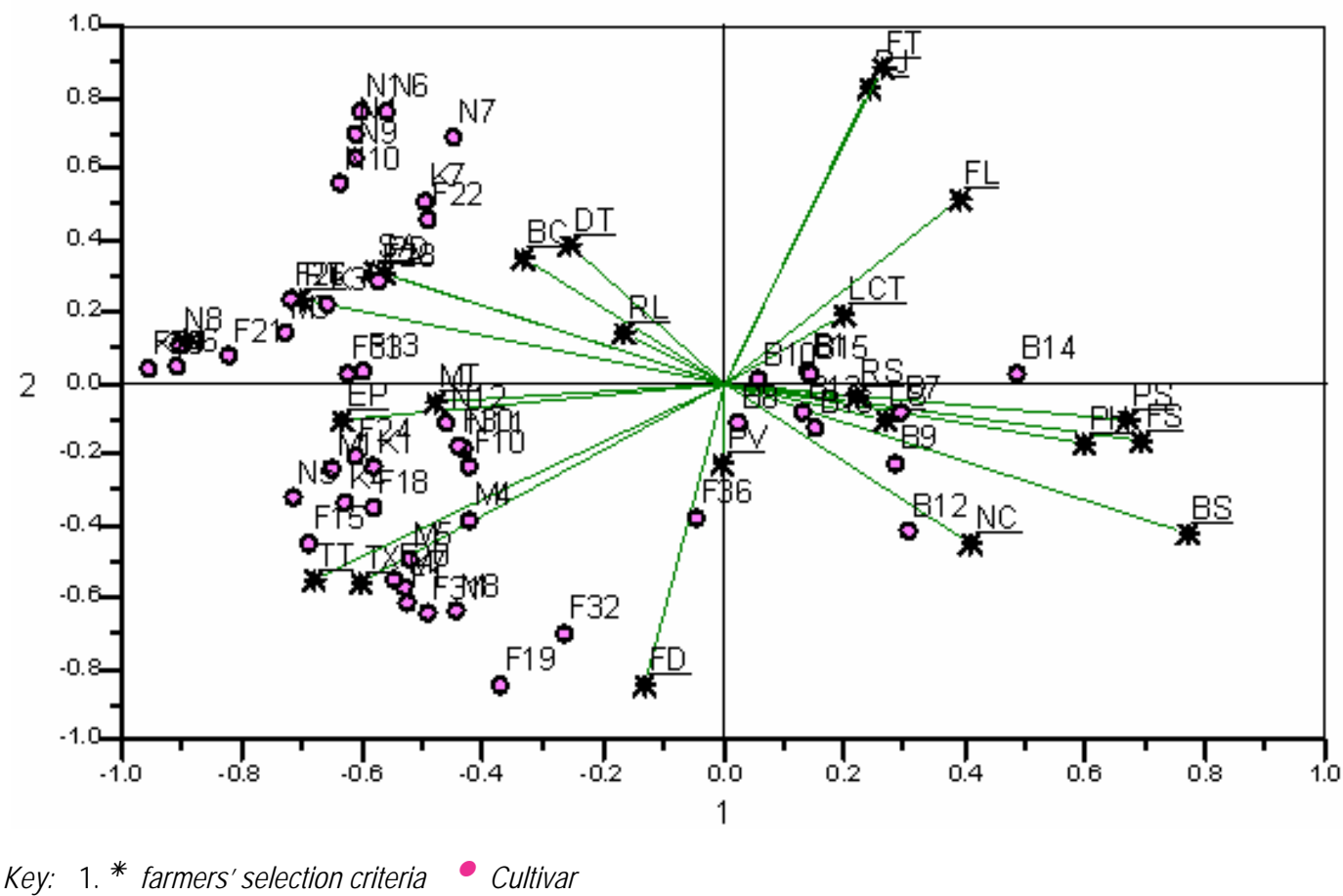

2. Cultivar Location-LCT; Soil adaptability-SA; Pseudostem size-PS; Bunch compactness-BC; Bunch size-BS; Brewing and Juice making-BJ; Drought tolerance-DT; Ease of peeling-EP; Flour-FL; Food-FD; Food security-FT; Finger size-FS; Texture-TX; Taste-TT; Maturity-MT; New cultivar-NC; Plant vigour-PV; Pseudostem height-PH; Ratooning-RT; Resistance to pests and diseases-PD; Rituals-RL; Roasting-RS; Leaf size-LS

3. B-Mbidde; F-Nfuuka; K-Nakitembe; M-Musakala; N-Nakabululu

4. Bagandeseza-B1; Kyamalindi-B10; Mbwazirume embidde-B11 Nalukira-B12; Nalwesaanya-B13; Nsowe-B14; Nunda-B15; Shombo-buleku-B16; Endemera-B2; Enigwa-B3; Enkara-B4; Enkundi-B5; Entabura-B6; EntukuraB7; Entundu (B)-B8 Kabula-B9; Atwalira-F1; Enzirabahima-F10; Enzirabahima omweru-F11; Kakirya-F12; Katwalo-F13; Kavube-F14; Kibidebide-F15; Kigerekyanvubu-F16; Kyabuyange-F17; Lusumba-F18; LwaduunguF19; Bukumu-F2; Mukazi-mugumba-F20; Musaj''atuuba-F21; Nabusa-F22; Nabusa-omuddugavu-F23; Nakawangaazi-F24; Nakawere-F25; Nakinyika-F26; Nalwezinga-F27; Nambi-F28; Nambi omumyufu-F29; Embogo-F3; Ndiibwa-balangira-F30; Nfuuka-F31; Ntika-F32; Pemba-F33; Ruzongoma-F34; Rwambarara-F35; Siira-F36; Engumba-F4; Enkonkomore-F5; Entariho-F6; Entokatoke-F7; Entundu-F8; Enyiraguju-F9; MbwazirumeK1; Mbwazirume omweru-K2; Nakitembe-K3; Namaliga-K4; Namaliga omunene-K5; Namwezi-K6; NandigobeK7; Africa-M1; Lwewunzika-M2; Lwewunzika-M3; Mpologoma-M4; Musakala-M5; Musakala omuddugavuM6; Musenene-M7; Muvubo-M8; Butobe-N1; Nakabululu omutono-N10; Nakyetengu-N11; Salalugazi-N12; Enteka katebe-N2; Entente-N3; Kattabunyonyi-N4; Kibuzi-N5; Mukubakkonde-N6; Nakabululu-N7; Nakabululu omudugavu-N8; Nakabululu omunene-N9.

Figure 4. Correlation between farmer cultivar selection criteria against cultivars in Masaka in Uganda.

is commercially based, so that only cultivars with good commercial end-uses are considered important during selection.

In general cultivar evenness was generally low in the three study areas indicating lower chances of occurrence of each cultivar recorded in each site. This is not good for conservation and measures need to be put in place to strengthen conservation before some cultivars are lost. 


\section{CONCLUSION}

The areas studied support a diverse collection of banana cultivars and using agro- morphological, agro-ecological and cultural selection criteria, farmers are able to conserve the diversity of bananas in mixed proportions. Mixed proportions can be explained in terms of cultivar richness and evenness to predict the conservation status of the crop. Diversity may be explained through indices which quantify proportions on farm and not just number of cultivars or cultivar mixture. It is now possible to predict in the near future which sites would maintain diversity overtime and those which will not, so that measures are taken to rectify the situation in order to conserve needed levels of diversity. In addition diversity in Musa sites is highly correlated with farmers' uses of individual cultivars.

\section{ACKNOWLEDGEMENT}

We wish to thank International Network for the Improvement of Banana and Plantain (INIBAP) for the financial support provided to carry out this work as well as the field equipments we used. We are thankful for the advice and support given by site extension workers (ARDI - Tanzania, Masaka and Bushenyi). We are grateful to John Ndamira (Bushenyi), Stephen Iga (Masaka) and Joseph Sekiku (Karagwe. Special thanks go to the farmers who participated in the research.

\section{REFERENCES}

Bellon, M.R. 1991. The ethnoecology of maize variety management: a case study from Mexico. Human Ecology 19:389-418.

Brush, S. 1991. A farmer-based approach to conserving crop germplasm. Economic Botany, 45: 153-165.

Brush, S. 1995. In situ conservation of landraces in centers of crop diversity. Crop Science 35: 346-354.

Brush, S. 1999. Bioprospecting the public domain. Cultural Anthropology 14(4): pp. 535-55.
Hammer, K. and Mbewe, D.N. 1992. The role of Traditional Knowledge in Germplasm collecting. In: Putter A. (Ed.), pp. 147-155. Safeguarding the Genetic Basis of Africa's Traditional crops. Technical Center for Agricultural and Rural cooperation. The Netherlands.

Karamura, D. A. 1999. Numerical taxonomic studies of the East African highland bananas (Musa-AAA-EA) in Uganda. A thesis submitted for the degree on Doctor of Philosophy, University of Reading.

Karamura, D., Mgenzi, B., Karamura, E. and Sharrock, S. 2004. Exploiting IK for the management and maintenance of Musa Biodiversity on farm. African Crop Science Journal 12(1): 71-78.

Louette, D. 1999. Traditional management of seed and diversity: what is a landrace? Chapter V, In: Brush S.B. (Ed.), pp. 109-142. Genes in the field. On-farm conservation of crop diversity. IPGRI (Rome), IDRC (Ottawa).

Maxted, N., Ford-Lloyd, B.V. and Hawkes, J.G. 1997. Complementary conservation strategies. In: Maxted, N., Ford-Lloyd, B.V. and Hawkes, J.G., (Eds.). Plant Genetic Conservation. The In Situ Approach. Chapman and Hall, London, UK.

Qualset, C.O., Damania, A.B., Zanatta, A.C.A. and Brush, S. 1997. Locally based crop plant conservation. In: Maxted, N., Ford-Lloyd, B.V., Hawkes, J.G., (Eds.). Plant Genetic Conservation. The In Situ Approach. Chapman and Hall, London, UK.

Teshome, A., Torrance, J.K., Baum, B., Fahrig, L., Lambert, J.D.H. and Arnason, J.T. 1999a. Traditional farmers' knowledge of sorghum (Sorghum bicolor [Poaceae]) landrace storability in Ethiopia. Economic Botany 53:69-78.

Teshome, A., Fahrig, L., Torrance, J.K., Lambert, J.D., Arnason, T.J. and Baum, B.R. 1999b. Maintenance of sorghum (Sorghum bicolor, Poaceae) landrace diversity by farmers' selection in Ethiopia. Economic Botany 53:7988. 